\title{
Effect of the environmentally friendly production systems on the vegetative characteristics of apple cultivars
}

\author{
Dremák, P., Csihon, Á. \& Gonda, I. \\ University of Debrecen, Faculty of the Agricultural and Food Sciences and \\ Environmental Management, Institute of Horticulture \\ 138. Böszörményi str., Debrecen, H-4032, Hungary, author for correspondence: Csihon, Á. (csihonadam@agr.unideb.hu)
}

\begin{abstract}
Summary: In this study effect of the environmentally friendly production systems on the brunch cross sectional area of apple trees trained to free spindle canopy are presented based on the data of 39 cultivars. According to our results branch thickness of the apple cultivars located in the lower, middle and upper region of the tree are more homogenous in the integrated production system compared to the organic one. Therefore the severity of the annual maintain pruning must be necessarily more moderate in the integrated growing system, than in the organic production system.
\end{abstract}

Dremák, P., Csihon, Á., Gonda, I. (2017): Effect of the environmentally friendly production systems on the vegetative characteristics of apple cultivars. International Journal of Horticultural Science 23(1-4): 11-14. https://doi.org/10.31421/IJHS/23/1-4./1194

Key words: integrated production, organic production, vegetative characteristics, brunch cross sectional area

\section{Introduction}

Integrated and organic protection systems are the only way of sustainable fruit production. These environmentally friendly production systems have the same fundamentals; however they show considerable differences in several practical aspects (Gonda, 2005; Holb, 2000, 2007, 2008, 2009). Generative processes and vegetative processes show different characteristics in organic production compared to integrated one which can be influenced greatly by the method and degree of phytotechnical operations (Gonda, 1979, 1993, 2005).

Zahn (1975) on sweet cherry trees determined the optimal thickness ratio between the central leader and the branches to create and maintain the canopies of the intensive orchards, which can be applied well also on apple trees. Based on his research thickness of the branches on the trunk must be under the half of the trunk thickness measured directly below the branch. According to Gonda \& Fülep (2011) the optimal value depends on the cultivars, so it is possibly to vary from the ratio 0.5 . For cultivars with weaker growth (cvs 'Idared' and 'Red Delicious' spurs) optimal value is $0.2-0.3$. In the case of $\mathrm{cv}$ 'Gala' 0.3-0.4 ratio can be named favorable, for the cv 'Jonagold' and the cv 'Red Delicious' the 0.4-0.5 values are optimal, while for cv 'Topaz' ratio over 0.5 is also optimal. Zahn-index of the main branches depends also on the age of the trees, namely numerous cultivars (cvs 'Gala DecarliFendeca', 'Gala Schnitzer-Schniga', 'Crimson Crisp', 'Jugala', 'Wiltons's Red Jonaprince', 'Red Idared', 'Jeromine') presented decreasing thickness values with increasing age (Csihon, 2015; Csihon et al. 2015). Application of Zahn's principles makes easier the pruning and facilitate the forming of airy, harmonic, conical or cylindrical shaped canopy with adequate illumination (Gonda, 1995).

In our recent studies (Dremák et al., 2015, 2016) effect of the integrated and organic production system on the thickness of the trunk and on the central axis was evaluated. In this paper effects of the two production systems on the brunch cross sectional area of the apple trees are evaluated.

\section{Materials and methods}

The study was performed at Pallag Experimental Station (University of Debrecen). Orchard was planted in 1997 with 39 apple cultivars. Trees were grafted on M.26 rootstock with $4 \mathrm{~m}$ x $1.5 \mathrm{~m}$ distances on free spindle crown form. Cultivars were grouped to three classes as worldwide known-, resistant- and historical Hungarian apple cultivars (Table 1).

Among the vegetative characteristics of the trees branch cross sectional area in three high levels (lower third, middle third, upper third) is presented. Five trees were observed per each cultivar. One typical branch was measured in each high level, which was expressed in $\mathrm{cm}^{2}$ value. Examinations were performed in apple trees aged 14, in 2010.

Table 1. Classification of the apple cultivars (Debrecen - Pallag, 2010)

\begin{tabular}{|c|c|c|}
\hline $\begin{array}{c}\text { Worldwide known } \\
\text { cultivars }\end{array}$ & $\begin{array}{c}\text { Resistant } \\
\text { cultivars }\end{array}$ & $\begin{array}{c}\text { Historical } \\
\text { Hungarian cultivars }\end{array}$ \\
\hline Gala Must & Pilot & Batul \\
\hline Golden Reinders & Reka & Mosolygós batul \\
\hline Csányi Jonathan & Relinda & Nyári fontos \\
\hline Ozark Gold & Renora & Téli aranyparmen \\
\hline Elstar & Reglindis & Téli banán \\
\hline Mutsu & Releika & Téli piros pogácsa \\
\hline Jonagold & Rewena & Darusóvári \\
\hline Golden Orange & Retina & Fertődi téli \\
\hline Ruby Gala & Remo & Francia renet \\
\hline Idared & Liberty & London pepin \\
\hline Granny Smith & Reanda & Gravensteini \\
\hline Pinova & Resi & Téli fehér kálvil \\
\hline Topaz & Faw 7262 & Húsvéti rozmaring \\
\hline
\end{tabular}


These parameters represent well the harmonic structure of the trees and the balanced growing. If the thickness of these branches decreases proportionally from the bottom to the up it can be assumed that the secondary, thirdrate twigs emerging from the main branches will be also proportionally thinner. Equilateral triangle shape means better lights conditions, which manifests in the balance of growing and bearing processes.

\section{Results and discussion}

\section{Branch cross sectional area in the lower region of the trees}

Nearly $50 \%$ of the bearing branches are located in the lower region of the trees. Thanks to their age and location they are the thickest parts of the canopy (after trunk and axis). Knowledge of their susceptibility to thickening is an essential information, namely their incidental excessive growth can break the balance inside the canopy. Unfavorably overthickened basic scaffold branches must be removed in time, as more year delay can cause notably yield loss.

Huge variability can be seen among the cultivars, as difference between the weakest and strongest branches is nearly 10 times (Figure 1). In the integrated system cv 'Gala' $\left(4.5 \mathrm{~cm}^{2}\right)$ and 'London pepin' $\left(5.4 \mathrm{~cm}^{2}\right)$ showed the weakest lower branches. About half of the cultivars displayed thickness under $10 \mathrm{~cm}^{2}$. Strongest growth (over $20 \mathrm{~cm}^{2}$ ) was observed with $\mathrm{cv}$ 'Francia renet' $\left(24.6 \mathrm{~cm}^{2}\right)$ and 'Gravensteini' $\left(36.5 \mathrm{~cm}^{2}\right)$.

It is also well visible that almost all cultivar presented thicker lateral scaffold branches in the organic production. Accordingly among these circumstances not only the trunk cross sectional area is higher in organic system, but also the branch cross sectional area. Larger branch thickness obviously means higher growing potential due their more developed vascular tissues. This also enhanced by the fact, that growing potential are distributed among less branches in organic farming, than in the integrated growing system where competition is higher thanks to the higher number of branches.

Practical significance of this phenomenon should be taken into consideration before the planting. For that reason planting design in the organic producing system must be higher (even with $20-30 \%$ ) to harmonize the growing processes and to avoid the negative effects of the volume restrictions of the canopy. This finding corresponds with the study of Gonda (2005), but in that study role of the scaffold branches is not detailed.

\section{Branch cross sectional area in the middle region of the trees}

Similarly to the previously mentioned, during the annual pruning overthickening branches should not be left neither in the middle region of the tree, as their late remove means

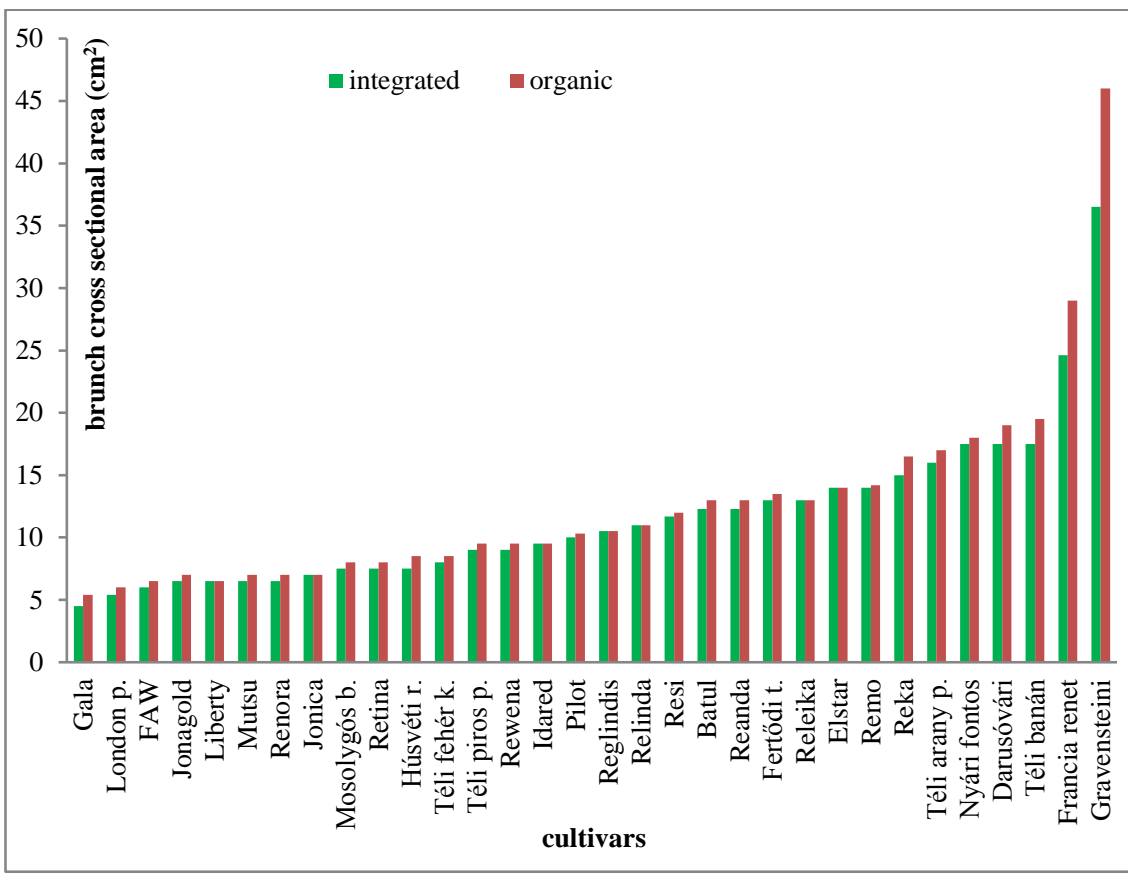

Figure 1. Cross sectional area of main lower branches of apple trees aged 14 (Debrecen - Pallag, 2010)

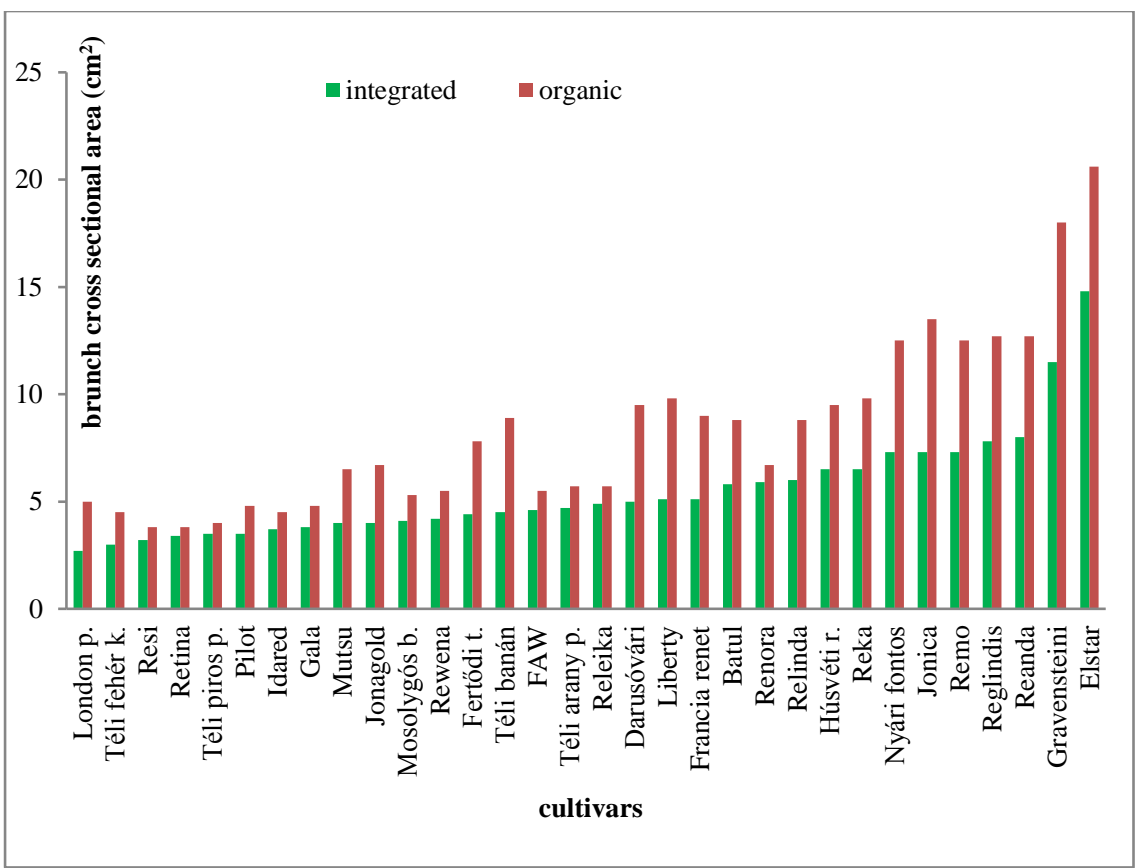

Figure 2. Cross sectional area of branches in the middle region of apple trees aged 14 (Debrecen - Pallag, 2010)

significant cropping surface loss which is needed to be trained again, if it is possible.

In the integrated system cv 'London pepin' $\left(2.7 \mathrm{~cm}^{2}\right)$ and 'Téli fehér kálvil' $\left(3.0 \mathrm{~cm}^{2}\right)$ reached the smallest brunch cross section area (Figure 2). Order of the cultivars shows quite balanced, steady growth regarding the cultivars with value under $10 \mathrm{~cm}^{2}$, namely sharp change in the order is not detected. Two cultivars presented thickness value above $10 \mathrm{~cm}^{2}, \mathrm{cv}$. 'Gravensteini' $\left(11.5 \mathrm{~cm}^{2}\right)$ and 'Elstar' $\left(14.8 \mathrm{~cm}^{2}\right)$.

In the organic farming system branch thickness of the middle region shows more significant differences compared to the more homogenous growth of the integrated system. $\mathrm{Cv}$ 'London pepin' with value of $5 \mathrm{~cm}^{2}$ is not anymore the cultivar 


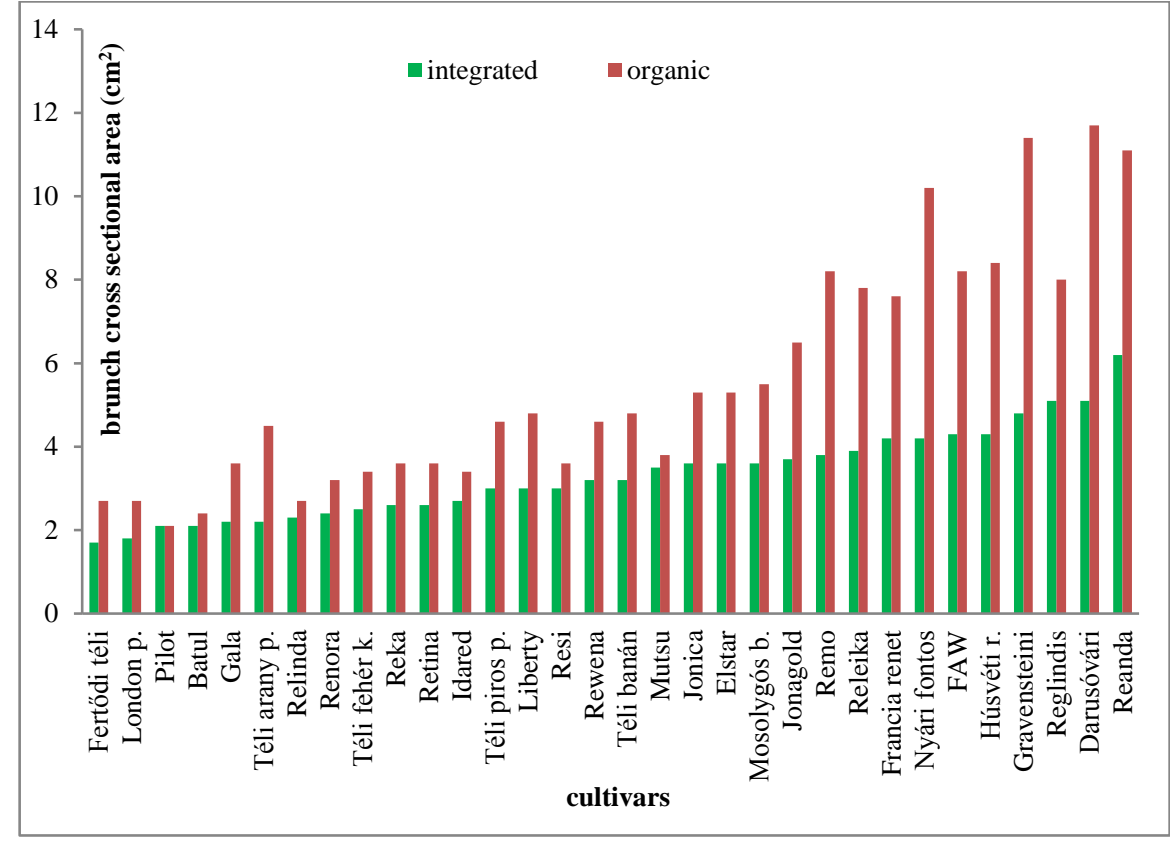

Figure 3. Cross sectional area of branches in the upper region of apple trees aged 14 (Debrecen - Pallag, 2010)

with the weakest branch. It is also well visible, that all cultivar reached higher thickness in integrated production than in the organic one.

Comparing the two production system it can be stated that the thickness of the branches in the middle region of the trees are more favorable in the integrated production, namely their thickness are more homogeneous, balanced, compared to the organic farming where the values are more scattered among and inside the cultivars.

\section{Branch cross sectional area in the upper region of the trees}

Vegetative characteristics of branches in the higher third of the canopies influence notably the possibility to maintain the trees in the appropriate space distances and keep the optimal height. Restriction or increase of tree height can be performed only hardly or not at all when thicker branches build up the higher zones of the trees. Furthermore excessive thick upper branches hinder the creation and maintenance of the optimal conical or cylindrical canopy shape which also makes worse the light utilization. Too thin twigs are also unfavorable, as increase of the tree height is limited.

In the integrated growing system cv 'Fertödi téli' showed the weakest branches $\left(1.7 \mathrm{~cm}^{2}\right)$, while cv 'Reanda' presented the highest value $\left(6.2 \mathrm{~cm}^{2}\right)$, as there is a four-fold difference among them (Figure 3).

Order of cultivars changes notably in the organic farming system compared to the integrated one, that is the scale of heterogeneity is growing. Difference between the weakest ('Pilot' $-2.1 \mathrm{~cm}^{2}$ ) and strongest ('Darusóvári' $-11.7 \mathrm{~cm}^{2}$ ) branches is more than 5.5-fold. Cultivars with lower values are easier to train, such as cvs. 'Pilot' $\left(2.1 \mathrm{~cm}^{2}\right)$, 'London pepin' $\left(2.7 \mathrm{~cm}^{2}\right)$, 'Fertödi téli' $\left(2.7 \mathrm{~cm}^{2}\right)$ and 'Batul' $\left(2.4 \mathrm{~cm}^{2}\right)$.

In accordance with the above mentioned the most difficult cultivars to handle in the two technologies those can be described with excessive thick branches in the upper region of the trees. For instance cvs. 'Nyári fontos' $\left(10.2 \mathrm{~cm}^{2}\right)$, 'Reanda' $\left(11.1 \mathrm{~cm}^{2}\right)$, 'Gravensteini' $\left(11.4 \mathrm{~cm}^{2}\right)$ and 'Darusóvári' $(11.7$ $\left.\mathrm{cm}^{2}\right)$.
Comparing the technologies huge differences are observed in the higher region of the trees among the cultivars. Thickness of the branches are practically twice larger with four cultivars in the organic farming than in the integrated one. These are cvs. 'FAW' (193\%), 'Releika' (195\%), 'Téli arany parmen' (197\%) and 'Remo' (198\%). Top of the tree is always dominant compared to other parts of the canopy thanks to its thickening susceptibility. Despite this fact it is surprising, that more than two times thicker branches were measured with cvs. 'Remo' (216\%), 'Darusóvári' (227\%), 'Gravensteini' (237\%) and 'Nyári fontos' $(238 \%)$ in the organic technology.

\section{Conclusions}

Eventually it can be stated that branch thickness of the apple cultivars located in the lower, middle and upper region of the tree are more homogenous in the integrated production system compared to the organic one. This means that the aim of the production is realized more efficiently with the trees in the integrated production, that is the thickness and the length of the branches are decreasing consistently from the bottom to the top, which results in conical, adequately illuminated canopy structure. Therefore the severity of the annual maintain pruning must be necessarily more moderate, than in the organic farming system.

Concerning the branches of the lower third of the canopy we found, that cultivars developed thicker branches in the organic production system compared to the integrated one. Similar tendency has been detected also in the middle and upper third of the trees. This means the benefits of the integrated system, where the trees with high density are more easy to train based on their vegetative characteristics, such as trunk, central leader and branch thickness.

\section{References}

Csihon, Á. (2015): Új almafajták növekedési, terméshozási és gyümölcsminőségi tulajdonságainak vizsgálata. Doktori értekezés. DE MÉK. 173. pp.

Csihon, Á., Holb, I., Gonda, I. (2015): Growing characteristics of apple cultivars and canopies. International Journal of Horticultural Science 21(1-2): 7-10. p.

Dremák, P. (2015): Környezetkímélő alma termesztéstechnológiák összehasonlító vizsgálata. Doktori (PhD) Disszertáció. DE MÉK. Debrecen. 152. pp.

Dremák, P., Csihon, Á., Gonda, I. (2015): Growing characteristics of apple cultivars in environmentally friendly growing systems. International Journal of Horticultural Science 21(3-4): 7-10. p.

Dremák, P., Csihon, Á., Gonda, I. (2016): Vegetative parameters of apple cultivars in integrated and organic production systems. International Journal of Horticultural Science 22(1-2): 15-18. p.

Gonda, I. (1979): Az erőteljes metszés hatása az almafákra. Kertészet és Szőlészet. 28(9): 5. 
Gonda, I. (1993): A fitotechnikai műveletek szerepe az alma integrált termesztés-technológiájában. Integrált termesztés a kertészetben (14.) 72-78.

Gonda, I. (2005): Az ökológiai növényvédelem közvetett elemei. In: Holb I. (Szerk): A gyümölcsösök és a szőlő ökológiai növényvédelme. 34-46. p. Mezőgazda Kiadó. Budapest.

Gonda, I., Fülep, I. (2011): Az almatermesztés technológiája. Debreceni Egyetem AGTC Kutatási és Fejlesztési Intézet, Gonda István Betéti Társaság, F. N. Fruit Kft. 260. pp.

Holb, I. J. (2000): Disease progress of apple scab caused by Venturia inaequalis in environmentally friendly growing systems. International Journal of Horticultural Science 6(4): 56-62.
Holb, I. J. (2007): Classification of apple cultivar reactions to scab in integrated and organic apple production systems. Canadian Journal of Plant Pathology 29(3): 251-260.

Holb, I. J. (2008): Timing of first and final sprays against apple scab combined with leaf removal and pruning in organic apple production. Crop Protection 27(3-5): 814-822.

Holb, I. J. (2009): Fungal disease management in environmentally friendly apple production. In: Eric Lichtfouse (eds.) Climate Change, Intercropping, Pest Control and Beneficial Microorganisms: Sustainable Agriculture Reviews 2. Dordrecht: Springer Science+Business Media B.V., 2009. pp. 219-293.

Zahn, F. G. (1975): Mabstabe für die Anzucht und den Schitt der Obstgehölze. Mitteilungen des OVR Jork 30: 93-109. p. 